University of Nebraska - Lincoln

DigitalCommons@University of Nebraska - Lincoln

Faculty Publications: Department of Teaching, Department of Teaching, Learning and Teacher Learning and Teacher Education

Education

2001

\title{
Validating the Draw-A-Science-Teacher-Test Checklist (DASTT-C): Exploring Mental Models and Teacher Beliefs
}

\author{
Julie A. Thomas \\ Texas Tech University, julie.thomas@unl.edu \\ Jon E. Pedersen \\ University of Nebraska-Lincoln, jpedersen2@unl.edu \\ Kevin Finson \\ Bradley University
}

Follow this and additional works at: https://digitalcommons.unl.edu/teachlearnfacpub

Part of the Teacher Education and Professional Development Commons

Thomas, Julie A.; Pedersen, Jon E.; and Finson, Kevin, "Validating the Draw-A-Science-Teacher-Test Checklist (DASTT-C): Exploring Mental Models and Teacher Beliefs" (2001). Faculty Publications: Department of Teaching, Learning and Teacher Education. 94.

https://digitalcommons.unl.edu/teachlearnfacpub/94

This Article is brought to you for free and open access by the Department of Teaching, Learning and Teacher Education at DigitalCommons@University of Nebraska - Lincoln. It has been accepted for inclusion in Faculty Publications: Department of Teaching, Learning and Teacher Education by an authorized administrator of DigitalCommons@University of Nebraska - Lincoln. 
Published in Journal of Science Teacher Education 12:3 (2001), pp. 295-310.

Copyright (C 2001 Kluwer Academic Publishers. Used by permission.

\title{
Validating the Draw-A-Science-Teacher-Test Checklist (DASTT-C): Exploring Mental Models and Teacher Beliefs
}

\author{
Julie A. Thomas \\ Texas Tech University, College of Education, \\ Box 41071, Lubbock, Texas, 79409-1071, U.S.A. \\ Jon E. Pedersen \\ The University of Oklahoma, College Of Education, \\ Science Education, 820 Van Vleet Oval ECH114, Norman, Oklahoma, 73019. U.S.A. \\ Kevin Finson \\ Bradley University, Teacher Education, \\ Westlake Hall 215, 1501 West Bradley Avenue, Peoria, Illinois, 61625, U.S.A.
}

\section{Introduction}

The National Science Education Standards [National Research Council (NRC), 1996] encourage science learning as an active, inquiry-based activity that children do rather than something that is done to them. Following the explicit goal of the standards to establish scientific literacy for all, students are expected to participate in hands-on and minds-on learning experiences that reflect the intellectual traditions of contemporary science. Standards-based lessons involve children in inquiry-oriented investigations, help them to establish connections, encourage questions, promote problem solving, and support group discussions. In the words of the standards,

Emphasizing active science learning means shifting away from teachers presenting information and covering science topics. The perceived need to include all the topics, vocabulary, and information in the textbooks is in direct conflict with the central goal of having students learn scientific knowledge with understanding (p. 20).

Today's preservice teacher experienced yesterday's K-12 science learning in the form of text-based, didactic lessons presenting science as an inert body of knowledge (Tobin, Briscoe \& Holman, 1990). No wonder science methods courses have done little to change the way science is taught in the elementary classroom (Raizen \& Michelsohn, 1994). Likely, the long history of traditional science learning experiences (in elementary school, high school, and college) powerfully impact the way in which elementary teachers understand the nature of science and the way in which science should be taught. This research begins with a concern for these experiences and resulting mental models and beliefs preservice teachers bring to science methods classes. 


\section{Mental Models}

Perceptions of ability and capability depend heavily on one's prior conceptualizations about oneself. These perceptions form internal, mental models of interaction (Norman, 1983). According to Norman, mental models provide (a) a belief system, reflecting beliefs acquired through observation, instruction, or inference; (b) observability, providing correspondence between the mental model and the physical world; and (c) predictability, allowing a person to understand and anticipate the behavior of a physical system. Barnes (1992), noting that one has a set of interconnected expectations before entering a schoolroom, suggested one's mental model is organized in "frames" or clustered sets of expectations. He explained that teachers' professional frames are both individually and socially derived - shaped by experiences as well as expectations and values (from the outside as well as the inside). Calderhead and Robson (1991) realized students held an image of good teaching which seemed to be derived from one or more teachers they knew, sometimes linking positive images to particular attributes of their own. Respected teachers, similar to student self-perceptions, seemed to reinforce the model; this was the kind of teacher they could see themselves becoming. Crow (1987) also reported teacher education candidates begin preparation programs with a well-established teacher-role-identity. Nespor (1987) argued that, though researchers have recognized the important influences of beliefs on teacher thinking, little attention has been given to the structure and function of teachers' beliefs about their roles, their students, the subject matter they teach, and the schools in which they work.

\section{Knowledge and Beliefs}

Clandinin and Connelly (1987) began to clarify the differences between knowledge and beliefs when they examined studies of teachers' beliefs. They discovered a plethora of terminology - teaching criteria, principles of practice, personal construct, personal theories, beliefs, perspectives, conceptions, personal knowledge, practical knowledge-and added their own term, personal practical knowledge, which they defined as experiential knowledge "embodied and reconstructed out of the narrative of a teacher's life" (p. 490). A variety of researchers continued to explore the structure of teachers' belief systems. Clark (1988) identified teachers' beliefs as preconceptions and implicit theories. He noted these beliefs seemed to be "eclectic aggregations of cause-effect propositions from many sources, rules of thumb, generalizations drawn from personal experience, beliefs, values, biases, and prejudices" (p. 5). Calderhead \& Robson (1991) reported that preservice teachers held vivid images of teaching from their experiences as students. These images affected students' interpretations of course experiences and powerfully influenced the translated knowledge and projected practices they would apply as teachers. Goodman (1988) favored the term teacher perspectives, noting two preservice students might express similar beliefs about teaching but the image associated with the expressions of their beliefs differed. Goodman (1988) discovered 
that teachers were influenced by guiding images from past events that created intuitive screens through which new information was filtered. Goodman's research further suggested early childhood school experiences have a significant impact on one's professional perspectives.

\section{Episodic Memory}

Nespor (1987) differentiated between knowledge and beliefs arguing that knowledge information is semantically stored, whereas beliefs reside in episodic memory drawn from experience. Nespor argued that beliefs draw their power from previous episodes or events that influenced the understanding of subsequent events. Further differentiating between knowledge and beliefs, Nespor explained knowledge systems are open to critical examination and beliefs are not; belief systems are likely to be unbounded and illogical while knowledge systems are more defined and receptive to reason. Comparing the two systems, Nespor found beliefs to be strong predictors of behavior and far more influential than knowledge in determining how individuals organize and define tasks and problems. Nespor (1987) reported beliefs to be basically unchanging, explaining that when beliefs do change, it is neither the result of argument or reason but rather a "conversion or gestalt shift" (p. 321).

The implications of episodic memory within knowledge and belief systems are especially important to this research, as these critical episodes or experiences are believed to influence and frame how one learns and how one uses what is learned. Nespor proposed that these richly detailed, episodic memories later serve as an inspiration or a template for one's own teaching practices. Other researchers have also noted the episodic nature of beliefs (Calderhead, 1988; Calderhead \& Robson, 1991; Clark, 1988; Goodman, 1988). Their studies suggest that students' educational beliefs significantly influence the perceptions and judgments they make about their own and others' teaching, as well as their interpretation and development of professional knowledge.

\section{Exploring Mental Images}

The developmental research reported in this study is connected to ongoing research regarding student perceptions of scientists, an extension of earlier research examining the perceptions and mental images students held about scientists. Student perceptions of scientists were first measured by Chambers (1983). The original Draw-A-Scientist-Test (DAST), patterned after Goodenough's DrawA-Man-Test (1926), was developed as an open-ended projective test to provide information regarding children's perceptions of scientists. Pictures were assessed according to seven, basic standard image elements. Chambers (1983) and Schibeci and Sorensen (1983) discovered that as children progressed through successively higher grade levels their images of scientists become more stereotypical, and that by fifth grade, the "image" had fully emerged. Finson, Beaver, and Crammond 
(1995) developed the Draw-A-Scientist-Test Checklist (DAST-C) to further consider alternative images and facilitate ease of assessment. DAST-C ANOVA preand post-course data indicated a significant shift $(p<.0001)$ from stereotypical images to more realistic images of the variety of persons involved in science as students increased contact with real-life scientists. For the research in this study, the DASTC was further modified to create the Draw-A-Science-Teacher-Test Checklist (DASTT-C). This test was expected to illuminate the knowledge and beliefs preservice elementary teachers construct prior to coursework in elementary science teaching methods.

DASTT-C development began with a listing of teacher-centered and student-centered attributes of an elementary science teacher rather than a scientist. This listing determined teacher-centered as those classrooms and teaching events where the teacher is at the center of instruction and learning. In this instructional model, the teacher is the knowledge conduit and the classroom environment is organized to facilitate the teacher as the knowledge conduit. Student input is acknowledged but not expected and the learning curriculum is focused on specific outcomes. In a student-centered classroom, the students are at the center of learning and the teacher guides or facilitates activities and investigations. The classroom environment is open and encourages student inquiry and exploration. Students manage their own learning and generally set the direction in which lessons proceed. These delineations were defined as polar opposites - one stemming from stimulus response theory (Brooks \& Brooks, 1993) and the other from constructivist theory (Dadydov, 1995). DASTT-C developers were not so much interested in "good" or "bad" teaching measures; thus each iteration of the checklist was modified to carefully eliminate any positive or negative connotations in the attribute lists. Given that Science for All Americans (American Association for the Advancement of Science, 1989) and the National Science Education Standards (NRC, 1996) position student-centered teaching at the core of the current reform movement, this instrument is intended to provide elementary preservice teachers with a reflective opportunity to (a) picture themselves as elementary science teachers, (b) place themselves along a teaching theory continuum, and (c) consider the ways in which they developed their own science teaching beliefs. Such a process might personalize the way in which the reform movement manifests itself in their own lives.

Now, in its third iteration, the DASTT-C includes both an illustration and a narrative data component. In order to determine a clearer picture of preservice teachers' self-perceptions of themselves as science teachers, the DASTT-C developers came to the conclusion that short, personal narratives might shed additional light on certain components or aspects or their drawings. Since oral interviews with each preservice teacher would be impractical, the developers added a written narrative component to the instrument. In pilot tests, this component was found to contribute some additional information as well as to confirm the evaluator's understanding of images in drawings. 


\section{Procedures}

\section{Instrumentation}

The present iteration of the DASTT-C score sheet (for the test administrator) consists of three sections: Teacher, Students, and Environment. Each section is scored in a dichotomous fashion with an indication of "present" or "not present" in the picture. The "Teacher" section of the instrument is divided into two subsections that focus on the teacher's activity (demonstrating, lecturing, using visual aids, etc.) and the teacher's position (location with respect to students, such as at the head of the classroom; and posture). The "Students" section of the instrument is likewise divided into two subsections that focus on the activities of students (passively receiving information, responding to the teacher, etc.) and students' positions (seated within the classroom). The third section, "Environment," consists of elements typically found inside classrooms, such as desks arranged in rows, symbols of teaching (e.g. chalkboards) and of science (e.g. science equipment), etc. Arbitrarily, each element in each section of the instrument is considered by the instrument's developers to depict teacher-centered elements of teaching and classroom images. If a teacher-centered element appears in a subject's drawing, the scorer simply marks that element on the checklist. Marks can later be added to derive both sub-scores for each section as well as an overall checklist score. Total checklist scores can range from 0 to 13 (the higher the score, the more teacher-centered the image). Given this score, students can place themselves on a continuum from student centered (0) to more teacher-centered (13) as indicated by the DASTT-C measure (see Appendices A-C for instrument, score sheet, and teaching style continuum). The DASTT-C Teaching Styles Continuum (derived from Simmons et al., 1999) serves as the report form for students. It is intended that students might first locate themselves on the continuum (according to the descriptions) and then consider the position determined by their DASTT-C score.

The newly revised response sheet provides blanks at the top for subjects to enter demographic information (identification number, date of drawing, preservice/ in-service status, etc.). In the center of the sheet is a square in which subjects are asked to make their drawing. Immediately above the square is the drawing prompt, "Draw a picture of yourself as a science teacher at work." Immediately beneath the square is another prompt, "What is the teacher doing? What are the students doing?" and some blank lines for subjects to begin describing their drawings. This descriptive narrative assists in scoring the drawing.

\section{Research Questions}

This research focuses on the following questions:

1. What mental images do elementary preservice students have of themselves as science teachers?

2. Is the newly revised DASTT-C instrument a valid measure of these images? 
The DASTT-C was administered to the preservice teachers during the first meeting of their science methods course. In the test administration, the only direction provided by the instructor was, "Draw a picture of yourself as a science teacher at work" and "Answer the question at the bottom $f$ the page to further explain the picture." Preservice teachers were provided the DASTT-C drawing page (requesting some demographic information at the top and providing a square space in the center of the page for the drawing), \#2 pencils (or markers) as desired, and 15-20 minutes to complete the test.

\section{Subjects}

The subjects for this iteration of the DASTT-C research include 27 elementary education majors attending a mid-sized regional four-year university. All were enrolled in their first elementary science methods course during the spring semester of the academic year. The students comprising the course sections were classified as juniors. Earlier studies have reviewed the illustrations of 850 preservice teachers and have served to support three adjustments in the DASTT-C instrument.

\section{Data Analysis}

\section{Reviewing Science Teaching Images}

Students generally respond quite favorably to the Draw-a-Science-Teacher exercise. Certainly the drawing process raises concern for some, but even in the definition of simple figures and sometimes-labeled features (for clarification purposes) students are easily motivated to think about what their own science classroom will look like. Further, they are open to questions about the meaning of the various features they include and a discussion sometimes raises interest in explaining the drawing or referencing features the student forgot to include. Most student illustrations can be organized into two fairly distinct groups: teacher-centered (7-13 points) and student-centered (0-4 points).

Teacher-centered illustrations (such as Figure 1) usually place the teacher in front of the class and include the backs of student heads (if students are referenced at all). The teacher is often teaching in front of a chalkboard or a chart that supports the lesson presentation (such as introducing the parts of a plant, explaining the process of a volcano eruption, or showing students the steps they will follow to make ice cream). Classroom organization frequently indicates the traditional rows placement of desks or chairs, but even when children are grouped they are working in a different area of the classroom than the classroom teacher. These images fit with teacher-centered thinking about subject matter knowledge being central to the learning process led by a teacher who organizes and delivers learning.

In student-centered illustrations, (like Figure 2) it is sometimes difficult to find the teacher (who is often labeled with an arrow or series of arrows to indicate movement). These teachers are doing activities with children (collecting leaves, planting bean seeds, observing a snake, or taking a field trip). Though many of these illustrations indicate an outdoor or museum learning environment, the classroom orga- 
nization usually includes more than the usual desks and chairs. These classrooms also include extra worktables or cabinets around the room for reference books, science equipment, and animals. These images fit more closely with standards-oriented or student-centered teaching following an exploratory approach to learning that encourages inquiry and questions facilitated by the teacher.

Draw a picture of yourself as a science teacher at work.

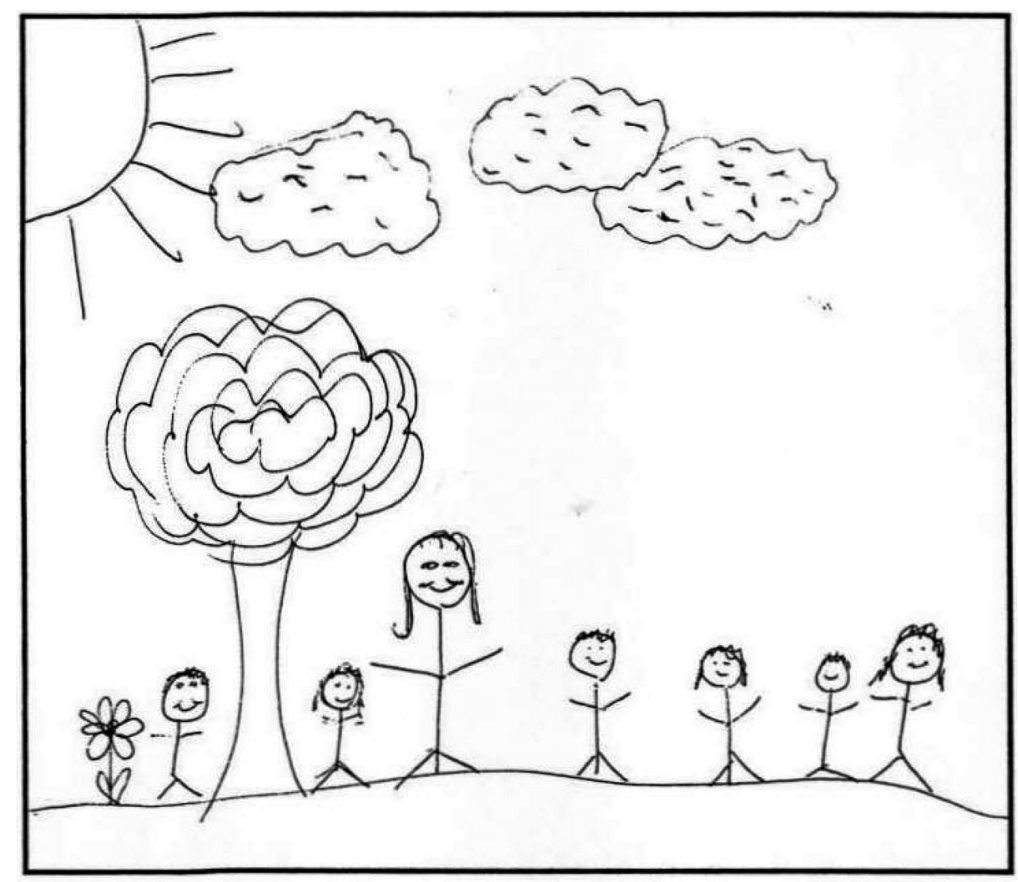

What is the teacher doing? What are the students doing?

The teacher is describing to her class what the experiment consists of and the specific safety rules to follow for the activity. The children are listening and putting their protective equipment on.

Figure 1. Teacher-Centered DASTT-C Picture and Explanation

This third version of the DASTT-C resolves an earlier scoring problem. The short student narrative helps define the meanings of the more illustrative images as well as the more abstract images. In the case of the illustrative images, the narrative helps to confirm the meaning of the images. With more abstract images, the narrative gives meaning to the symbols or metaphors indicated (thus a flashlight beam shining into an otherwise dark image space is understood to be the teacher enlightening students). While abstract image scores may not reflect the degree of student-centered or teacher-centered thinking as closely as illustrative image scores, they can be scored and can serve to guide student reflection. 
Draw a picture of yourself as a science teacher at work.

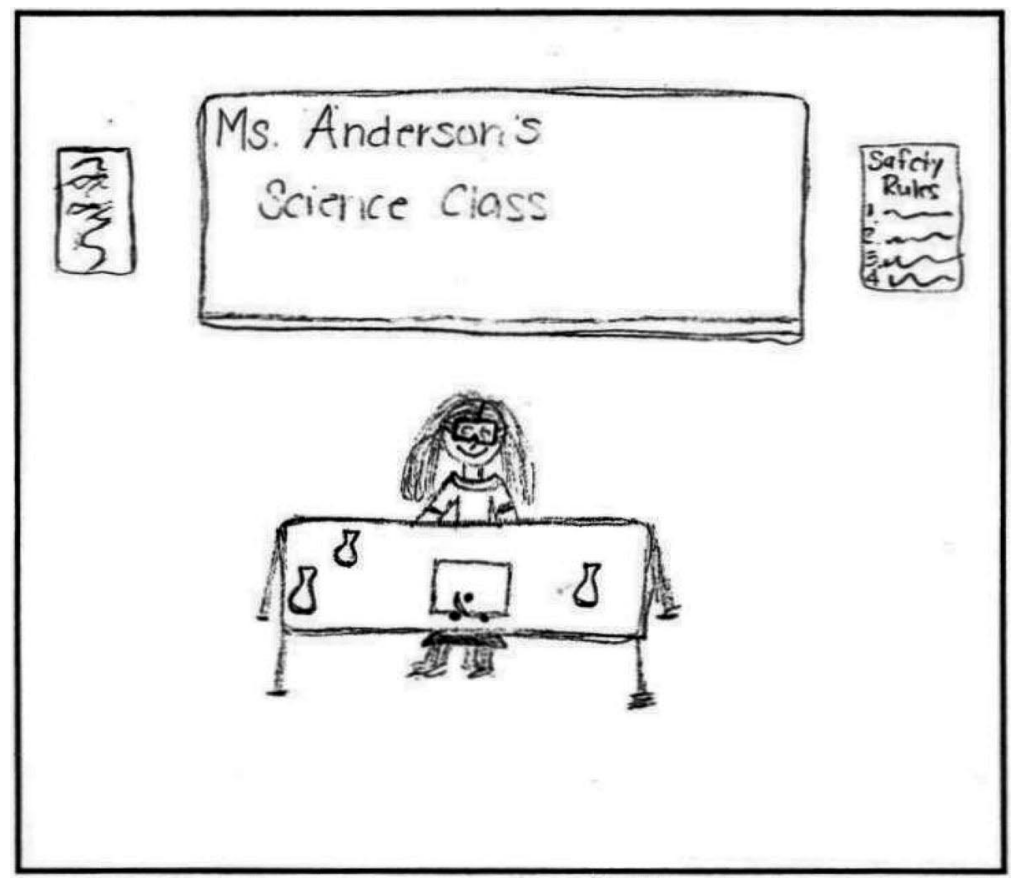

What is the teacher doing? What are the students doing?

As a teacher I am observing my students and helping everyone to get involved in the nature walk. The students are going to find objects that interest them to bring back to the classroom for us to discuss and study.

Figure 2. Student-Centered DASTT-C Picture and Explanation

\section{Testing Reliability and Validity}

To determine internal consistency or stability of the original DASTT-C, a pilot checklist was developed. The checklist indicators were derived from the DASTT$\mathrm{C}$ as well as from a review of the traditional and reform emphases as suggested in the new science teaching standards (NRC, 1996). Five raters checked 10 samples according to 11 criteria. A Phi Coefficient rating measured the association of scores between raters. Items receiving a rating of .70 or higher remained unchanged. Items rated below .70 were either eliminated or modified by clarifying the descriptors. The final form includes 10 criteria and three modified criteria. This form of the DASTT-C was then tested for internal consistency and for inter-rater reliability. Five (5) scorers, using the new form of the DASTT-C, scored the same set of pictures independently. In each case, individuals were asked to follow the scoring directions and score the complete set of pictures. An analysis of variance (ANOVA) was completed on the set of five scores examining the differences in the scores of each picture between the five (5) individuals. No significant difference was found 
in any of the sub scores or total scores of the DASTT-C. As well, the set of scores was used to determine a coefficient of internal consistency. A coefficient alpha was calculated for the data set since the DASTT-C produces dichotomous data. For dichotomous data, the coefficient alpha is equivalent to the Kuder-Richardson 20 (KR20) which uses the method of rational equivalence (determines internal consistency). The coefficient alpha for the DASTT-C is .82 indicating a high degree of internal consistency in the instrument. As well, all five individuals were asked to determine the face validity of the instrument. In each case, the five individual scorers indicated that the instrument appears to be relevant in terms of content.

\section{Discussion}

It seems preservice teachers develop mental models of elementary school science teaching from their experiences as elementary students (much like Chambers (1983) and Schibeci and Sorensen (1983) found with the stereotypic scientist image defined by fifth grade). Pre-course drawings suggest these models are somewhat modified by high school and college science experiences with high school and college experiences confirming the notions formed in elementary school. Additionally, preservice teachers' mental models and beliefs are highly correlated with specific, intense memories of the students' own science learning experiences in elementary, high school, and college science courses.

Frequent references to very specific room arrangements suggest students "bring" memories of previous science classrooms to their thinking about their own elementary classroom. References to a periodic chart in an elementary lesson or flasks and flames on the teacher's demonstration table indicate students' strongest (most memorable or perhaps most recent) memories include high school or college classrooms. Specific details to floor tiles, ceiling lighting, window arrangements or window dressings, and student work areas suggest preservice teachers are recreating components of their own science classroom experiences. Speech balloons (such as "learn this or else" and "help me") suggest personal, emotional memories as well.

The DASTT-C directs students to explore the ecology of their mental models and personal beliefs of elementary science teaching. Such exploration and reflection is critical given research that suggests that the educational beliefs of preservice teachers play a pivotal role in their acquisition and interpretation of knowledge and subsequent teaching behavior (Calderhead \& Robson, 1991; Clandinin \& Connelly, 1987; Clark, 1988; Goodman, 1988; \& Nespor, 1987). As Pajares (1992) contended, unexplored entering beliefs may be responsible for the perpetuation of antiquated and ineffectual teaching practices or cultural reproduction. Additionally, most students who choose to become teachers share positive identification with teaching, and this leads to continuity of conventional practice and reaffirming rather than challenging the past (Lortie, 1975).

Just as Hollingsworth (1989) promoted the possibility of educating preservice teachers who would challenge traditional, conservative school models - so too does the current reform agenda in science education. With this in mind, the 
DASTT-C can be a valuable tool to help teachers recollect memorable episodes within their beliefs about how to teach elementary science, consider alternative methodological approaches, and develop a preferred image of themselves as elementary science teachers. This preferred image might be a strong foothold in the continued development of increased confidence and understanding of new, standards-oriented science teaching. Certainly, science educators must provide opportunities for prospective teachers to examine critically the beliefs and knowledge they bring as well as those they reinforce during teacher preparation programs.

As applied to the DASTT-C, this research supports the notion that preservice teachers might very well possess perceptions of themselves teaching science that differ from those they actually employ once in a classroom with children. By analyzing the drawings with the preservice teachers, the DASTT-C developers believe preservice teachers can become more aware of possible differences between initial beliefs and actual practice (e.g. multiple interpretative frames), and thereby become more open to reflecting on their actual practice. While the current research focuses only on preservice elementary teachers, it is likely that this instrument and process might also be used with preservice middle level and secondary teachers. Certainly this notion is worthy of further investigation.

Pajares (1992) argued that a number of conditions must exist before a student can accommodate conflicting information and explained that students are generally unaware of exceptions or inconsistencies in their beliefs but that for conceptual change to take place, they need opportunities to test their beliefs. The DASTT-C instrument can support the process of conceptual change by helping students to think more deeply about science teaching methodologies - to juxtapose their own experiences with the teaching model they experience in their methods course and the teaching they observe in their field experiences. A review of their own illustration of themselves as an elementary science teacher can support personal reflection and challenge perceptions. The research of Simmons et al., (1999) suggests such an examination of beginning teachers' thinking could be used to plan more insightful learning experiences in the teacher preparation program.

\section{Implications and Recommendations}

Certainly, there is no one best way to teach elementary science all the time (Roseberry, Warren, \& Conant, 1992). Given that the National Science Education Standards recommend both process skills and content knowledge by grade levels, good teaching will no doubt require a blend of teacher-centered and studentcentered teaching skills - with standards-guided teachers knowing when to do what kind of teaching. Barnes (1992) proposed that the most effective teachers have multiple interpretive frames to help them see more alternatives and make better choices. To change one's beliefs, teachers need to discover that their existing frame for understanding what happens in their classroom is only one frame of several possible frames. When applied to science methods courses, helping preservice teachers come to understand their current perceptions or beliefs as only one possible interpretative frame might constructively contribute to more effec- 
tive changes in self- perceptions and ultimately in actual teaching practice. The DASTT-C might then serve to support reflection and challenge perceptions.

\section{Support Reflection}

The DASTT-C image can both begin and support long-term professional reflection about teaching elementary science. Reflection seminars and environments conducive to open inquiry, allowing for dissent and conflict, encourage students to explore their own and others ideas. Berlak and Berlak (1983) encouraged students to analyze a dilemma rather than to push them to defend a particular position. In this thinking, analyses of constraints and possibilities encourage thinking beyond criticism of current practice and generate thinking about genuine alternatives.

Goodman's (1988) research illustrated the need for a dialectical approach to research in teacher socialization. As Lortie (1973, p. 488) noted, the process of becoming a teacher is "complex ... not readily captured by a simple, one factor frame of reference." Including teachers in ongoing research on teacher thinking reflects ideological and political commitments of equitably shared power between the communities of research and practice. Clark (1988) recommended including techniques and opportunities for reflection and professional communication among teachers in our education program and demonstrating self-reflection and self-examination in our own teaching. Referring to the potential for reflection among practicing teachers, Clark suggested reflection could also rekindle professionalism, idealism, and commitment to self-improvement in veteran teachers as well.

\section{Challenge Perceptions}

Overall, teacher preparation programs need to develop strategies for helping students reflect upon their own and fellow students' perspectives. Goodman (1988) learned this reflection must necessarily go beyond what students "believe." He found, "If their beliefs were challenged in a non-threatening manner, most students seemed willing to seriously consider alternative points of view" ( $p$. 130). Opportunity for experimentation in field placements, reading, discussions, and conferences with faculty encouraged students to explore their beliefs. To significantly improve teacher preparation, we must first gain insight into the thinking, rather than just the behavior of future teachers (Buchmann, 1984; Peterson, 1988; Popkewitz, Tabachnick \& Zeichner, 1979).

Analysis of the DASTT-C image can lead preservice teachers to newly consider their mental models and beliefs of elementary science teaching practice. This can be particularly useful when done in non-threatening group sharing during methods course meetings or small group conferences with faculty outside of regular class time. Bullough, Knowles, and Crow (1991) emphasized the need for these contextual frameworks discussions to help preservice teachers become both students and architects of their own professional development. Clark (1988) suggested students need to discover their own preconceptions about teaching and learning-so that early field observations in the teacher preparation program 
might be structured to help make visible those important aspects of teaching that were not so obvious to them as primary or high school students. As Clark further recommended, faculty members might assume a changed, student-centered role of encouraging students to question their own thinking, perceptions, decisions, and intentions.

\section{References}

American Association for the Advancement of Science. (1989). Science for all Americans. Washington: AAAS.

Barnes, D. (1992). The significance of teachers' frames for teaching. In T. Russell and H. Munby (Eds.), Teachers and teaching: From classroom to reflection (pp. 9-32). New York, Falmer Press.

Berlak, A., \& Berlak, H. (1983). Toward a nonhierarchical approach to school inquiry and leadership. Curriculum Inquiry, 13 (3) 267-94.

Brooks, J. \& Brooks, M. (1993). In search of understanding: The case for constructivist classrooms. Alexandria: Association for Supervision and Curriculum Development.

Buchman, M. (1984). The use of research knowledge in teacher education and teaching. American Journal of Education, 92, 421-439.

Bullough, R.V., Knowles, J.G., \& Crow, N.A. (1991). Emerging as a teacher. London: Routledge.

Calderhead, J. (1988). The contribution of field experiences to student primary teachers' professional learning. Research in Education, 40, 33-49.

Calderhead, J., \& Robson, M. (1991). Images of teaching: Student teachers' early conceptions of classroom practice. Teaching and Teacher Education, 7, 1-8.

Chambers, D.W. (1983). Stereotypic images of the scientist: The Draw-A-Scientist Test. Science Education, 67(2), 255-265.

Clandinin, J., \& Connelley, F. (1987). Teachers' personal knowledge: What counts as 'personal' in studies of the personal. Journal of Curriculum Studies, 19, 487-500.

Clark, C.M. (1988). Asking the right questions about teacher preparation: Contributions of research on teacher thinking. Educational Researcher, 17 (2), 5-12.

Crow, N.A. (1987, April). Preservice teachers biography: A case study. Paper presented the annual meeting of the American Educational Research Association, Washington, D.C.

Finson, K.D., Beaver, J.B., \& Cramond, B.L. (1995). Development of and field-test of a checklist for the draw-a-scientist test. School Science and Mathematics, 95 (4), 195-205.

Goodenough, F.L. (1926). Measurement of intelligence by drawings. New York: Harcourt Brace.

Goodman, J. (1988). Constructing a practical philosophy of teaching: A study of preservice teachers' professional perspectives. Teaching and Teacher Education, 4, 121-137.

Lortie, D.C. (1975). School teacher: A sociological study. Chicago: University of Chicago Press.

National Research Council (1996). National science education standards. Washington, DC: National Academy Press. 
Nespor, J. (1987). The role of beliefs in the practice of teaching. Journal of Curriculum Studies, 19, 317-328.

Norman, D.A. (1983). Some observations on mental models. In D. Gentner, D., \& A.L. Stevens, (Eds.), Mental models (pp. 7-14). Hillsdale, New Jersey: Erlbaum Associates.

Pajares, M.F. (1992). Teachers' beliefs and educational research: Cleaning up a messy construct. Review of Educational Research, 62 (3), 307-332.

Peterson, P.L. (1988). Teachers' and students cognitional knowledge for classroom teaching and learning. Educational Researcher, 17 (5), 5-14.

Popkewitz, T., Tabachnick, B.R., \& Zeichner, K. (1979). Dulling the senses: Research in teacher education. Journal of Teacher Education, 30 (5), 52-60.

Raizen, S.A., \& Michelsohn, Eds. (1994). The future of science in elementary schools: Educating prospective teachers. San Francisco: Jossey-Bass.

Roseberry, A.S., Warren, B., \& Conant, F.R. (1992). Appropriating scientific discourse: Findings from language minority classrooms. The Journal of the Learning Sciences, 21, 61-94.

Schibeci, R.A., \& Sorensen, I. (1993). Elementary school children's perceptions of scientists. School Science and Mathematics, 83 (1), 14-19.

Simmons, Emory, Carter, Coker, Finnegan, Crockett, Richardson, Yager, Craven, Tillotson, Brunkhorst, Twiest, Hossain, Gallagher, Duggan-Haas, Parker, Cajas, Alshannag, McGlamery, Krockover, Adams, Spector, LaPorta, James, Rearden, \& Lubuda. (1999). Beginning teachers: beliefs and classroom actions. Journal of Research in Science Teaching, 36 (8), 930-954.

Tobin, K., Briscoe, C., \& Holman, J.R. (1990). Overcoming constraints to effective elementary science teaching. Science Education, 74 (4), 409-412. 


\section{Appendix A:}

\section{DASTT-C Instrument}

Date:

Location:
ID \#:

Preservice ( ) or In-service ( )

Draw a picture of yourself as a science teacher at work.

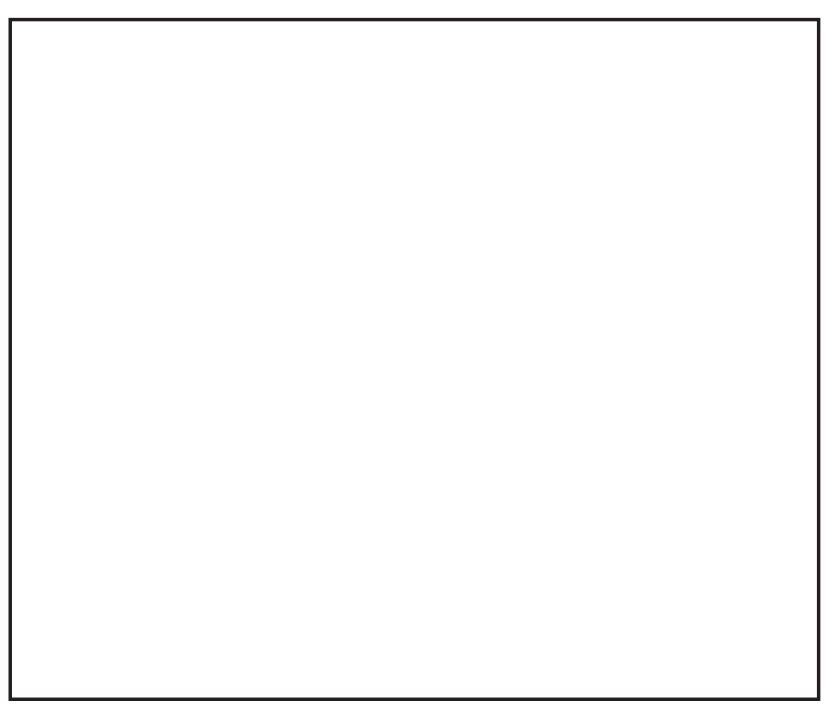

What is the teacher doing? What are the students doing?

(Version 2000) 


\section{Appendix B:}

\section{DASTT-C Score Sheet}

I. TEACHER

Activity

Demonstrating Experiment/Activity

Lecturing/Giving Directions (teacher talking)

Using Visual Aids (chalkboard, overhead, and charts)

\section{Position}

Centrally located (head of class)

Erect Posture (not sitting or bending down)

\section{STUDENTS}

\section{Activity}

Watching and Listening (or so suggested by teacher behavior)

Responding to Teacher/Text Questions

\section{Position}

Seated (or so suggested by classroom furniture)

\section{ENVIRONMENT}

\section{Inside}

Desks are arranged in rows (more than one row)

Teacher desk/table is located at the front of the room

Laboratory organization (equipment on teacher desk or table)

Symbols of Teaching (ABC's, chalkboard, bulletin boards, etc.)

Symbols of Science Knowledge (science equipment, lab instruments, wall charts, etc.) 


\section{Appendix C:}

DASTT-C Teaching Styles Continuum

\begin{tabular}{|c|c|c|}
\hline Exploratory (0-4) & Conceptual (5-9) & Explicit (10-13) \\
\hline $\begin{array}{l}\text { 1. Teacher believes stu- } \\
\text { dents are capable of } \\
\text { managing their own } \\
\text { learning. }\end{array}$ & $\begin{array}{l}\text { 1. Teacher believes stu- } \\
\text { dents need themed, } \\
\text { conceptual learning } \\
\text { experiences. }\end{array}$ & $\begin{array}{l}\text { 1. Teacher believes stu- } \\
\text { dents lack knowledge } \\
\text { and need assistance in } \\
\text { learning. }\end{array}$ \\
\hline $\begin{array}{l}\text { 2. Curriculum is open to } \\
\text { student interests. }\end{array}$ & $\begin{array}{l}\text { 2. Content is exploratory, } \\
\text { organized around key } \\
\text { concepts. }\end{array}$ & $\begin{array}{l}\text { 2. The curriculum is fo- } \\
\text { cused on specific } \\
\text { outcomes. }\end{array}$ \\
\hline $\begin{array}{l}\text { 3. Teacher leads and } \\
\text { guides student activi- } \\
\text { ties/ investigations. }\end{array}$ & $\begin{array}{l}\text { 3. Teacher organizes the } \\
\text { connections of con- } \\
\text { tent and processes of } \\
\text { science. }\end{array}$ & $\begin{array}{l}\text { 3. Teacher is the knowl- } \\
\text { edge conduit (telling is } \\
\text { teaching). }\end{array}$ \\
\hline $\begin{array}{l}\text { 4. Teacher focuses on stu- } \\
\text { dent questions as an in- } \\
\text { structional goal. }\end{array}$ & $\begin{array}{l}\text { 4. Teacher-centered les- } \\
\text { sons include hands-on } \\
\text { activities, group work, } \\
\text { and discussion of ideas. }\end{array}$ & $\begin{array}{l}\text { 4. Teacher initiates activ- } \\
\text { ities. Student input is } \\
\text { acknowledged but not } \\
\text { expected. }\end{array}$ \\
\hline $\begin{array}{l}\text { 5. Alternative assessment } \\
\text { measures student learn- } \\
\text { ing and knowledge. }\end{array}$ & $\begin{array}{l}\text { 5. Tests check for under- } \\
\text { standing of important } \\
\text { concepts. }\end{array}$ & $\begin{array}{l}\text { 5. Tests focus on science } \\
\text { content knowledge. }\end{array}$ \\
\hline Column total: & Column total: & Column total: \\
\hline
\end{tabular}

\section{Directions}

1. Read across each row. Check the column that best describes your beliefs.

2. Add the check marks in each column.

3. Compare your column totals. How does your teaching style choice align with your DASTT-C score? 